\title{
Surfaces
}

\section{Bill Readings and the supplement}

\section{Beatrice Skordili}

Volume 6, 1996

LES ÉCONOMIES DISCURSIVES DU SAVOIR ET DE LA CULTURE DANS LE SILLAGE DE L'OEUVRE DE BILL READINGS

THE DISCURSIVE ECONOMIES OF KNOWLEDGE AND CULTURE, WITH CONSTANT REFERENCE TO THE WORK OF BILL READINGS

URI : https://id.erudit.org/iderudit/1064864ar

DOI : https://doi.org/10.7202/1064864ar

Aller au sommaire du numéro

Éditeur(s)

Les Presses de l’Université de Montréal

ISSN

1188-2492 (imprimé)

1200-5320 (numérique)

Découvrir la revue

Citer cet article

Skordili, B. (1996). Bill Readings and the supplement. Surfaces, 6 . https://doi.org/10.7202/1064864ar
Résumé de l'article

« Bill Readings et le supplément » est une tentative de tracer les connections variées entre les écrits de Bill Readings sur Milton, à partir de son éthique de la lecture et de l'écriture, de ses positions pédagogiques en classe et de ses relations avec ses étudiants; et finalement de sa relation avec le nom. Cet essai imagine de dresser les rudiments d'une grapho-biographie qui se juxtapose elle-même à des lectures psychoanalytiques - avec leurs implications de maîtrise. 


\title{
Bill Readings and the supplement
}

Beatrice Skordili

English Department

Syracuse University

bskordil@mailbox.syr.edu

Surfaces Vol. VI. 219 (v.1.0A - 26/12/1996) - ISSN:

1188-2492

Copyright for texts published in Surfaces remains the property of authors. However, any further publication should be accompanied by an acknowledgement of Surfaces as the place of initial publication.

\begin{abstract}
"Bill Readings and the supplement" is an attempt to trace the various connections of Bill Readings' work on Milton with his ethics of reading and writing, his pedagogical stance in class and relationship to his students, and finally his relationship to the name. The paper imagines setting up the rudiments of a symptomatic grapho-biography that juxtaposes itself to psychoanalytic readings-with their attendant implications of mastery.
\end{abstract}

\section{RÉSUMÉ}

Bill Readings et le supplément est une tentative de tracer les connections variées entre les écrits de Bill Readings sur Milton, à partir de son éthique de la lecture et de l'écriture, de ses positions pédagogiques en classe et de ses relations avec ses étudiants; et finalement de sa relation avec le nom. Cet essai imagine de dresser les rudiments d'une grapho-biographie qui se juxtapose elle-même à des lectures psychoanalytiques - avec leurs implications de maîtrise. 
What, then, calls me into question most radically?

Not my relation to myself as finite or as the consciousness of being

before death or for death, but my presence for another who absents himself by dying.

To remain present in the proximity of another who by dying removes himself definitively, to take upon myself another's death as the only death that concerns me, this is what puts me beside myself, this is the only separation that can open me,

in its very impossibility, to the Openness of a community.

(Blanchot, Unavowable Community)

To write as I shall do now about the work and pedagogy of a man who was my teacher, to write in his absencewhat is more-to ascribe meaning to his everyday transactions with a group of people that were his students, can only be some kind of betrayal: an acknowledgment that Bill is dead, that having faded in the real, he now appears in the symbolic as meaning for me, and perhaps for others. I write, nevertheless, in the hope that what actually gets produced is not meaning as such but a "metonymic prolongation" of the encounter that this class was, or of my relation to the person I then called "Uncle Bill"-an English uncle! Bill Readings is not simply a horizon of meaning, a name that indexes a body of work, let me say this and have done, but the very materiality, the embodiment of a collective affection. He affects us still that is, and-at that-as a member of a community that avows nothing, except the fact that it has encountered its openness in his death: not its limit, but the possibility of maintaining him as a phantasmatic materiality.

Yet the strange logic of the supplement prevails; this patch over the wound left by the transplanting of the poem serves only to reveal the very scar it hides. (Readings, "An Age Too Late") 
The material temporality of the linguistic event is not the "materiality of the signifier" in that language does not say nothing, but always says something more than nothing: in language, even silence speaks. (Readings, "An Age Too Late")

(...) another fall, that between text and footnote. (Readings, "An Age Too Late")

A great deal of critical energy has been expended on discussing the historical minutiae of Milton's life and works. This is ironic given that Milton himself expressed total contempt for footnotes, consistently privileging historical argument over historical scholarship. This course will try to examine the relation of the oeuvre of Milton (an historian himself) to the question of history and of historical time. We'll look at the timeliness of Milton's own writings as both a historical and a theoretical question. Milton does not simply write in history but theorizes historical time as a problem of and for writing and reading, a problem that recurs throughout the tradition of criticism and commentary upon Miltonic writings. (Readings, "Milton, History and Psychoanalysis")

In this introductory paragraph to his syllabus for English 766, "Milton, History and Psychoanalysis," Bill Readings outlined the issue that was to be the focus of our class, the same one finds in the first chapter of his unfinished book on Milton, and the one that defines what I have come to see as Bill Readings' relation to Milton. Milton taken up with the issue of history, favoring "historical argument over historical scholarship," becomes an object of historical scholarship himself; nevertheless, as Bill Readings put it in "An Age Too Late," the first chapter of his unfinished book on Milton, "the flagrant anachronism of literary history is grounded in Milton's own flagrant anachronism"(2). Already in that first paragraph Bill Readings brings Milton's contempt for footnotes to bear on his thought about Milton's relation to history.[ 1 ] While there is no doubt that Bill Readings' central preoccupation in the course, as well as the first chapter of his book-which were, by the way, contemporaneous[ $\underline{\mathbf{2}}$ ] -was Milton's inauguration of historicity, history as an object of speculation, Milton's contempt for footnotes and for supplementarity in general-which is the condition of language-seemed to preoccupy him a lot. 
The following quote from "The Reason of Church Government" is an example of Milton's condemnation of scholarhip that consisted of "marginal" commentary:

(...) and there be fain to club quotations with men whose learning and belief lies in marginal stuffings, who, when they have like good sumpters laid ye down their horseload of citations and fathers at your door, with a rhapsody of who and who were bishops here or there, ye may take off their pack-saddles, their day's work is done, and episcopacy, as they think, stoutly vindicated. (Milton, "The Reason of Church Government," 671)

Milton is referring to Biblical commentary and a whole body of theological works dating from the time of Catholic Church dominance, which not only had eclipsed the Bible but authorized the prelatic law of Church government that Puritans like Milton fought against. Here is how Bill Readings comments on this quote and on Milton's general aversion to supplementarity as well as the general tendency of critics to practice exactly what Milton was chastising:

Thus Milton's critics relentlessly annotate his texts in the name of historical scholarship, ignoring the proleptic condemnation implicit in Milton's remarks in The Reason of Church Government on "men whose learning and belief lies in marginal stuffings." In the words of Colasterion, the "good health" of the poem should not depend upon "the gout and dropsy of a big margent, litter'd and overlaid with crude and huddl'd quotations." John Hollander speaks persuasively of the condition of Paradise Lost as effectively self-alluding, comparing Milton to Keats in that "there is no reliance on the reader's possession of the text referred to-it is almost as if the echo would appeal, not to the audience for an allusion but the surrounding poem itself." This internalization of allusion, as poetic self-echo may be more generally understood as a kind of self-footnoting. Our annotations to the poem mark only our declivity from it: we fall with Mulciber even as we triumphantly annotate Milton's rejection of annotation, his dismissal of his own allusion to Homer in the description of his Fall. (...) One might even go so far as to say that the space between "relate" and 
"erring" not only mimes the distance of Mulciber's fall but reminds us of another fall, that between text and footnote. This is not so much a rejection of footnotes as a proleptic mockery of the condition to which Milton seeks to reduce the reader, that of literary historian. We read only at the price of accepting his originality and our secondariness-there will be no more poetry, only footnotes to the historical object: literature." (Readings, "An Age Too Late," 31-3)

The main argument of "An Age Too Late" is that Milton inaugurates literary history as the condition by which his own text, Paradise Lost, may be read, while he is also inventing history as an object of speculation for a subject separated from and thereby able to survey history from a distance. After Milton, scholars are forced to resort to commentary if they are to speak of Milton or his work at all. Miltonic self-reflexivity, as Bill Readings discusses it in this quote, is the means by which literary and other contexts become part of the text of Paradise Lost, the way Milton secures for his text the impossibility of a margin. Properly understood, Milton's intention was to make classical texts allude to Paradise Lost, and not the inverse. Literary history begins with Paradise Lost precisely because Paradise Lost itself rewrites it own position in literature, preceding yet not predating the texts of classical literature.

Bill Readings has taken note of the fact that "Milton exerted an almost unprecedented degree of control over the publication of his manuscripts ... to the extent that textual editors have had to invent topics of controversy in the absence of stimulating variant readings"(4-5). Milton's attitude towards his own texts indicates, according to Bill Readings, an attempt to preempt any future attempt not only to date his work, but also to establish the process by which it came about.

Milton's poetry proleptically contains the tradition of its reading, not because it says everything there is to be said about itself, but because it situates the Fall and the Incarnation as linguistic events and as the origins of language and of time. The brief indications I've given of the critical tradition show that it has tended to remain faithful to Milton's effort to situate the Fall as false origin, a deviation, understanding the task of commentary to redeem the Fall in revealing the Incarnate meaning of the text once more, in a critical 
Second Coming. (Readings, "An Age Too Late," 49-50)

Paradise Lost situates the bar between signifier and signified as a historical event, the Fall. The Fall is the event that inaugurates history as the concatenation of signifiers that approximate but never reach the Incarnate meaning that is Christ-the Word; language reduces us to the anticipation of a Second Coming that will put the period to our sentence. The bar between signifier and signified is infinitely mirrored in the impossibility of the text to authorize itself except at the margin that infinitely divides it from its own authority. In a tour-de-force of signification Milton inverts the allegory of the Fall as fall into language, thereby subordinating the Biblical narrative to the event of language that allows us access to it.

The elimination of the process of the signifier, is entirely consistent with Milton's view of the Bible which, as Bill Readings pointed out repeatedly, maintains that the Biblical text makes ecclesiastical commentary entirely superfluous.[ $\underline{\mathbf{3}}$ ]

That which is moral, besides what we fetch from those unwritten laws and ideas which nature hath engraven in us, the gospel, as stands with her dignity most, lectures to us from her own authentic handwriting and command, not copies out from the borrowed manuscript of a subservient scroll, by way of imitating. (Milton, "The Reason of Church Government," 648)

The Bible, according to Milton, reads itself out to us, it allegorizes itself in the written text, which is nothing but a distorted version mediated by writing. The written version of the Bible becomes an allegory of the transcendent Bible; Milton claims that the allegorical and the literal meanings are inverted. By extension, writing constitutes the supplement to the Bible's identity. Miltonic scholarship, according to Bill Readings, invariably affirms Milton's desire to have signified an unsupplemented language, and also to have produced a text that allegorizes itself as "incarnate meaning." The effects of Paradise Lost position critics vis-à-vis the text at the other side of the divide of language; fallen themselves, they have to affirm the Miltonic text at the expense of their own project.[ $\underline{4}$ ] Bill Readings' project on Milton can only be understood as an attempt to come to terms with the text of Paradise Lost by taking an entirely different tack, neither a footnote to the poetic 
text, nor an eulogy of Milton, "An Age Too Late" starts to diagram a new relation to supplementarity, a displacement and an answer.

(...) only reading as a kind of metonymic prolongation. (Readings, "An Age Too Late")

To become "answerable," a stylus must "go too far," reading (or re-writing) must take responsibility for itself as act. Reading the event, the event of reading attains the style of a sublime excess over recognizable origins, albeit micrological. (Readings, "An Age Too Late")

Bill Readings approached the issue of writing after Milton as a fundamental ethical challenge: having suggested that after Milton "there will be no more poetry, only footnotes to the historical object:

literature"(33), Bill Readings laid out the possibility of a reading and a writing that will not be a supplement to the literary object, necessary and yet superfluous.

However, I am not arguing that events, or Milton's poetry, transcend history so as to stand "outside" it-which is to say, this is not an idealist argument so much as an antimodernist materialism. There is no "outside" here, since events are not arranged in parallel, as competing revelations of a big truth. Metonymic rather than metaphoric, they are linked in a series, in a sequence from which there is no emancipation; no understanding or metaphoric substitution, only reading as a kind of metonymic prolongation. (Readings, "An Age Too Late," 38-9)

A series of observations that need not bear a hierarchical relation to the text above or below, peripheral or central, a parataxis of text and context, this is the kind of reading Bill Readings envisaged as the means by which he could encounter Milton in the face of an enormous body of scholarship. Reading as a "metonymic prolongation" of the text $[\underline{\mathbf{5}}$ ] eschews meaning as the central preoccupation, it prefers an extension of the effects of the text; instead of a paradigmatic juxtaposition of signifier to signified, this type of reading, instead names 
the paradigm as one of the conditions of a syntagmatic extension, and meaning as a mirage.

Meaning is merely one possibility for linking, not the only one. To put things more bluntly, to read metonymically is to ask what to write after Milton rather than what to write about Milton or to duplicate what Milton means. Thus my writing here is not detached from Milton: neither separated from certain texts nor offering a meaning (a "Milton") that may be put in place of them. (...) My reading prolongs Paradise Lost in another context and as such, it can't take Milton for granted but must wager itself against the counter-claims of more pressing critical issues or of silence. (Readings, "An Age Too Late," 42)

Bill Readings tries to forge a relation to Milton that does not fall prey to the conditions by which Milton wished to circumscribe the condition of writing after him. Bill Readings does not choose to approach Milton's text as though his reading might be the meaning of Milton's text; on the contrary, he wishes to come to terms with his exclusion from Paradise Lost, to come to terms that respect yet do not succumb to Milton's demand.

Rather than a bold originality, what follows is a metonymic inflection of "answerable style."

And this metonymic inflection involves thinking "answerable" in terms of response rather than identity, as a matter of what to say next rather than just one of mimetic reflection. Likewise, to "attain" a "style" is not simply to engage in formal imitation of an original but to pick up a pen, after an original. This does not mean that these metonymic responses are performed in a present that is utterly blind to the meanings and forms of the past, utterly given up to present contingency. "Answerable style" does not mean that one can say whatever one likes but that the just response to a text is not just a matter of accurately reflecting its meaning, be it formal or contentual. (Readings, "An Age Too Late," 42)

As we begin to hear the inflections of Bill Readings inimitable "style" we begin to measure the insistence of the word "just" in his sentences-a reference, undoubtedly to Jean-François Lyotard's Au Juste (translated in English as Just Gaming).[ $\underline{\mathbf{6}}$ ] Troping on the semantic field of the signifying displacement of the word "just," Bill Readings 
is not satisfied with exactitude, "mere" meaning, but rather a notion of response-ability that requires making explicit the polysemy entailed in signifying practices: a game, a prolongation of the conversation, a rhetorical shifting of ground whereby "just" attains its exactitude the moment it loses its servility. Hence "answerable style" implies le mot juste, the right turn of phrase, the clever rather than the appropriate response.

From "metonymic prolongation" to "answerable style," the transition that Bill Readings effects is not simply one of elaboration. "Metonymic prolongation" refers in a sense to the effects of the encounter with the text, a negotiation of the demands of meaning that are invariably placed on the critic. "Answerable style" is an attempt to couch this metonymic extension in terms of authority, to make the encounter with Milton, and his demand to have circumscribed everything that can be said about his text, an other authority, one which authorizes a conversation.

Metonymically speaking, I write "about" Milton in the sense that I write around him, in the margins of his text, next to it and without the protective distance of the marginal footnote. Reading with a metonymic inflection, we don't abandon metaphor as the false imposition of a "truth." Reading "after" means that we encounter a debt to the past, not that we reduce the past to a collocation of illusory stereotypes, false meanings to be transcended as we relinquish a notion of "meaning" entirely. Self-divided between metaphor and metonymy, no phrase is ever simply meaningful nor utterly meaningless. In the play between the two lies the risk of the necessity of reading, the chance of/for reading, as it were. The chance of reading is always there, but reading only occurs when it goes too far, exceeds complacent mimesis to run the risk of saying something more, something unwarranted, unexpected. In moving beyond what is warranted, reading "happens" and becomes "answerable" for its own happening. (Readings, "An Age Too Late," 42-3)

From now on, called to the bar of history, we will sit alone at the bar, our only sense of belonging lying in the capacity to order "the 
usual," the "solitus" that marks our lonely community. (Readings, "An Age Too Late")

The supplement holds a peculiar fascination, a fascination that Milton was wont to curtail by proliferating the kind of wordplay that deprives the pun of pleasure; neither morbid, nor funny, Milton's puns were invariably serious, however clever. Milton's linguistic virtuosity lay in perfecting a kind of chiasmatic pun that inverted allegorical and literal meanings to suggest a prelapsarian language; this overdetermination of meaning is precisely the reason for the inability of literary critics to escape merely footnoting the Miltonic text. Bill Readings, however, met "Milton at the Movies, "[ 7 ] and then took him to a bar. Punning, a virtual epidemic in certain parts of the Syracuse University English Department when Bill Readings was there, is a certain concession to the supplement; frivolous, exorbitant, exhibitionist some said, ludic and libational, the pun is the affirmation that the supplement, the signifier, can be intoxicating. Hence, the end of Paradise Lost seems to unleash in Bill Readings a wild desire to inebriate the Miltonic text, to unhinge its perfect chiasmatic structure, and to rail at literary history a bit:

At the end of Paradise Lost Adam and Eve are subjects, the stress on "solitary," attached as it is to a revision of the wedded bliss of Eden's "handed they went." The uncanny nature of their isolation is a relation to history: "solitus" as "customary" lies behind "solitary," by a false etymology. From now on, to be in hand no longer holds expressive immediacy: weddings are to be customary. We have passed from intuition to institution. At the same time, our subjective isolation, the "solitary" is situated over and against our dwelling in the customary past, the habitual habitus from which we have been expelled. From now on, called to the bar of history, we will sit alone at the bar, our only sense of belonging lying in the capacity to order "the usual," the "solitus" that marks our lonely community. Only by a false etymology, repugnant to literary history, can we connect the "solitus" with our sole status. At the end of Paradise Lost stands the figure of humanity, condemned to the living death that is literary history. (Readings, "An Age Too Late," 30)

Characteristic of Bill Readings as this quote is, lugubrious and hilarious at the same time, it should not 
simply serve as a reminder, or as "the usual" reference to a deceased person's charming qualities, a solitus, a solace! On the contrary, let us note that in this very move, Bill Readings reveals his own peculiar relationship with the supplement; true to his own injunction for a metonymic prolongation of the text that carries a reading too far, Bill Readings exacerbates the supplement through a false etymology, that brings him inevitably to the bar of the linguistic sign, the bar of history, and to a bar[ 8 ] with Milton. Supplementarity, the condition by which idealism gives way to a certain dependence on materiality, a burden for Milton yet the very possibility of his poetry, is for Bill Readings an ethical injunction.

In the context of a course intensely taken up with issues of supplementarity, it is doubtful that Bill Readings might have escaped a thought or two about the supplements to and of his own teaching. Such training for his students as the rudimentary knowledge of using concordances and dictionaries, examining varieties of sources, and preparing class presentations and applications for grants, must have been clearly indicated as means to displace authority in a classroom that could have become suffocatingly teacher-centered-especially given the extent of Bill Readings knowledge and scholarship on Milton. However, I seriously doubt that Bill Readings consciously chose to supplement his teaching presence with all the other supplements that enable human relations: dinner parties, excursions to local bars, participating in group sports and attending conferences en masse. I detect in this constant proliferation of supplements to the teacher-student encounter an emergent ethics that also indicates a modesty, for which Bill is not customarily known.

In making the class an occasion for also doing Milton, in foregrounding the community, as opposed to the object of study, Bill Readings put into action his "answerable style"; rather than subordinating the class to the text, the text occasioned the class and our conversations. We learned a lot about Milton that semester, but at no time were we required to make Milton our project in the way that it must have been for Bill Readings-engaged as he was in writing his book at that point. Hence, the supplements to scholarship which were intended to enable us to think as incipient scholars, the supplements to the classroom relation which were instrumental in developing friendships, these supplements constitute in 
my mind a decision on Bill Readings' part to understand the classroom not as a place where ideas interact, but as the site of a relation among people, and this not under the guise of an ideological humanism-"We are all people! Let us relate as people!"-but in the very specificity of a group that was not as harmonious as one might imagine. I say this not to suggest that some of the participants were more or less devoted to the class, to Bill Readings or to Milton-that goes without saying; I say this not having been the most devoted of them all to the class, to Bill Readings, and, most especially, to Milton. On the contrary, I want to suggest that when Bill Readings started formulating his "metonymic prolongation" of a reading, which he insisted had nothing to do with idealistic argumentation but on the contrary with a certain materialism, he was indeed going further than he may have imagined, he was setting up the terms by which his own classroom functioned, and also the terms by which, in retrospect, I would come to understand that classroom.

Bill Readings repeatedly suggested that a reading should go too far, and that this is the condition by which it may actually say something.[ $\underline{\mathbf{9}}$ ] Hence, I am not upholding Bill Readings' relation to the supplement as a conscious pedagogical stance, this would reduce Bill's behavior to morality rather than charm, which he not only possessed but notoriously cultivated. Having brought about in my text a succession of shifts from a thought in Milton about supplementarity, to Bill's relation to Milton, to Bill's relation to reading, and finally to Bill's practices, I have not assigned so much a meaning to his actions, but rather brought about an encounter, a conversation that sustains him in my work. To write therefore about this class simply because it would shed light on the person and scholar Bill Readings, would simply be to say that Bill belonged to his students a little more than to the readers of his texts-or in another sense that we belonged a little more to him. However, to write, in his phantasmatic presence, is not to speculate, it is to enable a thought that leads to the question of the process by which a thinker's work becomes transformed into a scholarly practice, a conscious ethics, and then ends up troping his everyday exchanges: this implies the possibility not only that we can assign a pedagogy to Bill Readings, but also that Bill Readings enables us to speculate on our own pedagogy, precisely because he enables us to formulate this question. 
"Readings" is clearly a very loaded term here ... (Readings, "An Age Too Late")

I never heard Bill Readings pun on his name, or it may be that I was too fresh a graduate student then to catch the nuanced wordplay that such an obvious pun requires. Nevertheless, I do not doubt that Bill Readings must have felt that at least as far as names went he had a distinct advantage over Jacques Lacan's fairly suggestive "à la cantonade," and Jacques Derrida's rather cumbersome "J'accuse de rideau." However, the signifier in this case affords little room for humor, as the following quote demonstrates:

"Readings" is clearly a very loaded term here, and working out what is at stake in its use will require most of (and require the most of) this book. One cannot determine in advance what it will be to read. Here, however, are three hints:

(i)Reading is a process of experimentation or invention, rather than understanding.

(ii)Reading is aimed at justice rather than truth, at deciding what is responsible or just to say next, to link next in the series of events. (iii) The demand of responsibility (or "answerable" response, as Milton put it) is what distinguishes experimentation from lawlessness and gives us something to argue over. Remaining with Milton, one may say that what is at stake between these two temporalities, between history and the event, is the task of criticism, as well as poetry, in finding an "answerable" phrase for the event that we seek to read. (Readings, "An Age Too Late," 39)

Hence a series of theoretical tropes: A name that signifies only when written, différance for beginners! What is more a signified which allegorizes itself in the act of signifying, chiasmus worthy of Milton! The very "instance of the letter in the unconscious," and "thename-of-the-father" combined! Derrideans and Lacanians alike could get a little of their own back, if they were inclined to hold a grudge for the aforementioned advantage Bill Readings holds over the two Jacques. However explanatory of Bill Readings' course of studies and scholarship, however indicative of why the book on Milton was never finished over the course of five years, this paragraph still says "something more than nothing"as Bill himself would have remarked: Having read Bill 
Readings' name in this quote, there still remains for us to read the quote, and then to read and write after it.

\section{Works Consulted}

Benjamin, Walter. Illuminations. Trans. Harry Zohn. New York: Schocken Books, 1969.

Blanchot, Maurice. The Unavowable Community. Trans. Pierre Joris. Barrytown: Station Hill Press, 1988.

Burke, Kenneth. Attitudes Toward History. Berkeley: University of California Press, 1984.

Derrida, Jacques. Of Grammatology. Trans. Gayatri Spivak. Baltimore: Johns Hopkins University Press, 1974.

Hughes, Merritt Y. ed. John Milton: Complete Poems and Major Prose. New York: Macmillan Publishing Company, 1957.

Jameson, Fredric. Marxism and Form: Twentieth Century Dialectical Theories of Literature. Princeton: Princeton University Press, 1971.

Lyotard, Jean-François \& Thébau, Jean-Loup. Just Gaming. Trans. Wlad Godzich. Minneapolis: University of Minnesota Press, 1985.

Readings, Bill. "An Age Too Late." Unpublished work on Milton, 1991.

Readings, Bill and Schaber, Bennet eds. Postmodernism Across the Ages. Syracuse: Syracuse University Press, 1993.

Readings, Bill. "Milton, History, and Psychoanalysis." Syllabus for English 766, a graduate seminar, Spring 1991.

\section{NOTES}

1. In fact Bill Readings could not have been more right to make this association between a thought about history 
and a thought about footnotes. My own research brought forth the rather systematic thought deriving from Marxism on the question of footnotes and their relation to history: Fredric Jameson cites a paragraph by Adorno as an example of "a complete footnote" (Jameson, Marxism and Form, 9). Being a Marxist, Jameson sees the footnote as a means of inserting history in philosophical speculation; in it he sees the possibility of allowing context to enter the text. In addition, Kenneth Burke-not a marxist but certainly someone who has engaged marxism in his work-in a footnote at the end of his Introduction to Attitudes Toward History suggests that if his text was made up entirely out of footnotes it would acquire a form "better suited to [its] material."

2. Bill Readings admitted that he decided to teach the seminar because he had started to write the book, so when he finished the first chapter he distributed it to the class, asking us for feedback if we had any; this is actually how I came to have his chapter.

3. In Of Grammatology Derrida defines the supplement as both a "surplus" and a "substitute," "a plenitude enriching another plenitude" (Derrida, 144-5). Another equally pertinent quote given Milton's project is the following: According to Rousseau, the negativity of evil will always have the form of supplementarity. Evil is exterior to nature, to what is by nature innocent and good. It supervenes upon nature. But always by way of compensation for ... what ought to lack nothing at all in itself. (Derrida, 145)

$\underline{4}$. Oddly, this was also the fate of the paper I wrote for Bill Readings' seminar: I was hopelessly deadlocked between a deconstructive reading gone awry and the almost hysterical desire to prove that the linguistic project of Paradise Lost had failed. As I was struggling with the obdurate text, Bill offered no consolation: he predicted, and was confirmed, that so long as I continued fighting Milton my paper would not finish.

5. "Metonymic prolongation" was a phrase for which Bill had had to endure relentless teasing, from some of us. I recall that at some point Bill, a little exasperated, suggested that maybe it was an unfortunate phrase. Unfortunate, manquée, the phrase is perhaps a mistake, but certainly not an error, as such it is the best phrase to describe Bill's project.

6. For the sake of accuracy, I should say here that credit for the book equally goes to Jean-Loup Thébaud, the other party to the singular dialogue that Just Gaming is. 
The book was a definite favorite of the two twins, Bill Readings and Bennet Schaber-inseparable, dressed identically, co-teachers, co-authors, they even had their own secret language. In that secret language, "Just Gaming" was always rendered "Just Naming" with conspiratorial delight, undoubtedly as a reference to the infamous punning and name-dropping practices of theoreticians.

7. The reference is to an essay that Bill Readings wrote for Postmodernism Across the Ages, a collection of essays he co-edited with Bennet Schaber.

8. To the bar is also where Bill used to take his students quite often, and not because he, or any of us for that matter, needed a drink that badly-Milton can conceivably reduce people to this condition-but just so, because it was the Bill Readings thing to do.

9. This was in fact not only a phrase from his chapter but also one of the comments that he wrote on the back of one of my papers, to admonish me, for having become too squeamish of my own conclusions. Rather the opposite of what a teacher usually suggests to a student, the comment demonstrates that Bill Readings was formulating a set of practices rather than a theory of reading when he wrote "An Age Too Late."

Accueil Surfaces | Table des matières | Recherche $\underline{\text { Surfaces Home Page | Table of Contents | Search }}$

PUM | Livres | Revues | Publications électroniques | Vente et distribution 